\title{
Assessment of Application Conditions of Infiltration Basins for Regulation of Urban Rainwater Drainage
}

\author{
Olexander Tkachuk ${ }^{1}$, Yana Yaruta ${ }^{1 *}$, Olha Shevchuk ${ }^{1}$ \\ 1 National University of Water and Environmental Engineering, 33028 Soborna St., 11, Rivne, Ukraine \\ * Corresponding author's e-mail: ia.v.yaruta@nuwm.edu.ua
}

\begin{abstract}
Regulation of surface runoff in urban areas with temporary delay by infiltration basins of rainwater in the places of their precipitation and with gradual drainage through the existing reservoirs of small diameters is the most appropriate under the conditions of intensive building development, wear and imperfection of surface drainage systems, especially combined sewerage. Evaluation of application conditions and basic parameters of infiltration basins in surface drainage regulation was carried out on the basis of own experimental studies of infiltration basin fragment with upper typical vegetation layer, numerical computer modeling of surface runoff formation in urban areas, its regulation using infiltration basins and analysis of previous studies. Its water absorption, filtration and clearing indicators were defined on the basis of experimental studies. The self-regenerative restoring function of a vegetative layer, working conditions under the flooded and not flooded conditions were established and defined. According to the amount of suspended solids, BOD, oxidation, $\mathrm{pH}$ and dissolved oxygen, the quality of rain runoff when filtering water through the upper vegetation layers of infiltration basins decreases to the normative values.
\end{abstract}

Keywords: water drainage, infiltration basin, surface drainage, urban areas, surface runoff quality.

\section{INTRODUCTION}

Significant climate changes observed in recent decades lead to heavy rains and storms (Ukrainian Hydrometeorological Center, 2021; Fletcher et al., 2013]. At the same time, intensive building development, the lack and inadequate technical condition and treatment of the rainwater drainage system, most of which in Ukrainian cities are combined, lead to flooding and inundation of urban areas, as well as pollution of surface runoff of settlements and water objects (Boshota, 2013; Tkachuk \& Yaruta, 2018; Shevchuk, 2017; Dziopak, 2015; Low impact development stormwater management planning and design guide, 2020). Therefore, the regulation of surface runoff on the territory of any settlement is becoming increasingly important. The most appropriate method of regulation is the temporary delay of rainwater in the places of their precipitation by using infiltration basins with the gradual removal of these waters through the existing reservoirs of small diameters or the use of retained water for domestic purposes (Shevchuk, 2017; Yaruta, 2020; Dziopak, 2015).

With this regulation of surface runoff, rainwater accumulates in infiltration basins, which reduces peak loads on drainage collectors and pipes. They allow preventing not only flooding and inundation of urban areas in low-lying areas, but also ensure the retention of pollution during rainwater filtration through the upper vegetation layers of infiltration basins (Boshota, 2013; Tkachuk \& Yaruta, 2019; Yaruta, 2020; Kaźmierczak, 2013; Lucke \& Nichols, 2015). Further discharge of such pre-treated surface water into water objects significantly reduces their pollution.

The infiltration basin (Fig. 1) is an underground reservoir (Yaruta, 2020; Lucke \& Nichols, 2015; Low impact development stormwater management planning and design guide, 2020) with waterproof walls, filled with a porous load for water accumulation. In the upper part of the basin construction there is a soil layer with vegetation, 

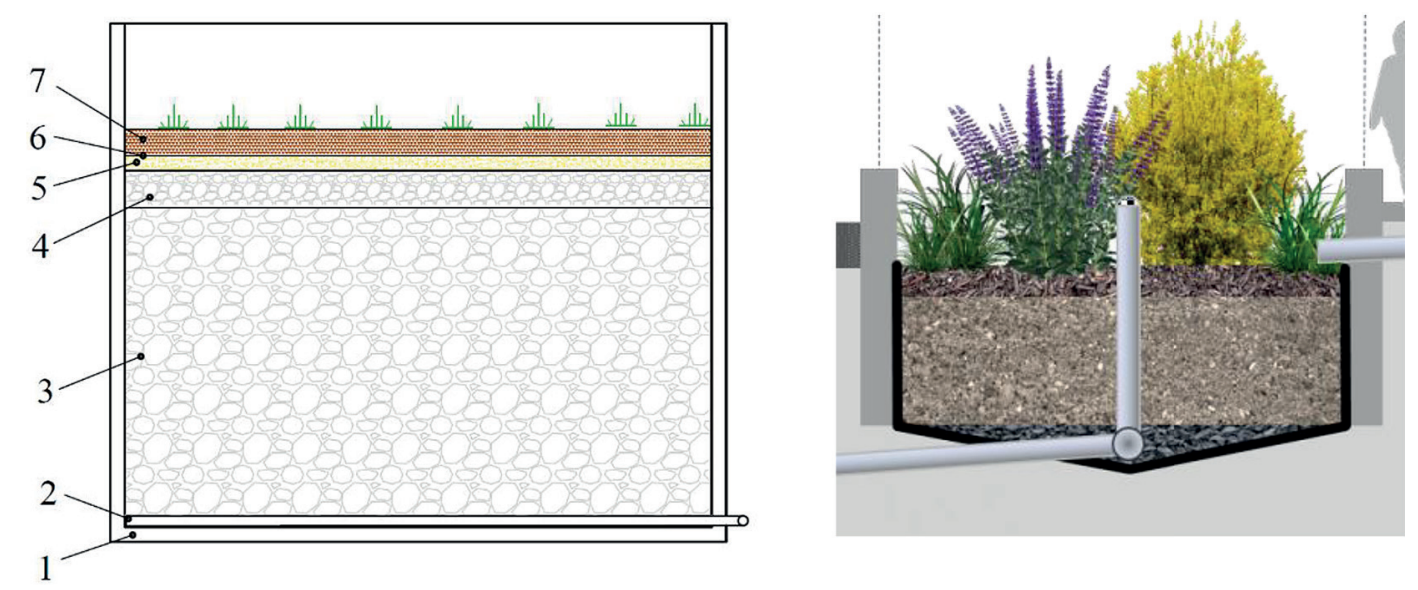

Figure 1. Variants of structural construction of infiltration basins:

1 - waterproof walls; 2 - drainage pipe; 3 - accumulating loading layer;

4 - bearing layer; 5 - sand layer; 6 - geotextile; 7 - soil-vegetation layer.

which provides pre-treatment of surface runoff. In the lower part of the basin construction, there is a drainage system for collecting and draining the retained water. It can enter the collectors of the existing drainage system, in the well for dismantling for domestic purposes or discharge in drainage trenches when groundwater levels are low.

Infiltration basins can operate in both flooded and non-flooded modes. Experimental studies of a fragment of the infiltration basin with the upper typical vegetation layer showed (Yaruta, 2020) that the flooding of its surface begins with the intensity of rain runoff over $9 \mathrm{~mm} / \mathrm{min}$. This occurs during prolonged heavy rains and large catchment areas in front of infiltration basins. In flooded mode, the space above the vegetation is an additional space for temporary accumulation of water.

Infiltration basins can operate in both flooded and non-flooded modes. Experimental studies of a fragment of the infiltration basin with the upper typical vegetation layer showed (Yaruta, 2020) that the flooding of its surface begins with the intensity of rain runoff over $9 \mathrm{~mm} / \mathrm{min}$. This occurs during prolonged heavy rains and large catchment areas in front of infiltration basins. In the flooded mode, the space above the vegetation is an additional space for temporary accumulation of water.

In order to assess the conditions of application and the main parameters of infiltration basins in the regulation of surface drainage in urban areas, experimental studies of a fragment of infiltration basin with the upper typical vegetation layer were conducted. They included: determining its filtration and purification indicators, establishing self-regenerative function, conducting numerical computer modeling of the processes of surface runoff formation in urban areas, joint operation of infiltration basins with collectors of drainage networks and analyzing similar studies by other authors. As a result of the analysis the following basic conditions and restrictions of application of infiltration basins in urban systems of surface runoff drainage were defined. They are:

- urban-planning - establish possible locations of infiltration basins;

- technological - determine the allowable conditions of inflow, accumulation and drainage of wastewater;

- ecological - determine the possible conditions of preliminary surface water treatment, the need for additional treatment according to certain indicators, the impact on urban flora;

- economic - determine the economic feasibility of construction and maintenance of swimming basins within acceptable urban, technological and environmental conditions.

Assessment of the conditions and restrictions on the use of infiltration basins implies a strict sequence: first - urban (without the available areas for the basins, others lose their meaning); further - technological (providing parameters of inflow, accumulation and drainage of sewage within their admissible normative values); then - environmental and economic for the options that are responsible for the previous conditions.

The number and size of infiltration basins depend on the volume of rainwater to be retained, the conditions of runoff formation in urban 
development areas with a certain type of pavement, the porosity of the storage layers, as well as the amount of water drainage associated with the water absorption properties of infiltration pavements and technical parameters of drainage systems (DBN V.2.5-75:2013, 2013; DSTU-N B V.1.1-38:2016, 2016; Tkachuk \& Yaruta, 2018; Shevchuk, 2017; Yaruta, 2020; Lucke \& Nichols, 2015; Low impact development stormwater management planning and design guide, 2020).

As a result of research (Tkachuk \& Yaruta, 2018; Yaruta, 2020) it was found that the volume of rainwater to be regulated in the area of runoff, $W_{\text {reg }}$ should be calculated by the formula:

$$
W_{\text {reg }}=W_{\text {reg }}^{\prime} \cdot W_{r} \text {, }
$$

where: $W_{\text {reg }}^{\prime}$ is the relative regulated volume of rainwater to be regulated, the share of the unit $\left(W_{r e g}^{\prime}=0 \ldots 1\right)$.

$W_{S}$ is the amount of rain runoff inflow to the infiltration basin:

$$
W_{s}=k_{\text {dim }} \cdot q_{r} \cdot t_{r}=k_{\text {dim }} \cdot z_{\text {mid }} \cdot \frac{A^{1.2}}{t_{\AA}^{1.2 n-1.1}} \cdot F,
$$

where: $k_{d i m}$ is a dimension coefficient, which depends on the dimension of the input and the resulting parameters of the formula (DBN V.2.5-75:2013, Annex A, 2013]; for $q_{r}, 1 / \mathrm{sec}\left(t_{r}, \min , F\right.$, ha) and $W_{r}, \mathrm{~m}^{3},-$ $k_{\text {dim }}=0,06$;

$q_{r}$ is an estimated flow of water flow to the infiltration basin, $1 / \mathrm{sec}$;

$t_{r}$ is an estimated rain duration, $1 / \mathrm{sec}$; $z_{\text {mid }}$ is an average value of the runoff coefficient, which depends on the types of coverage of individual areas and their share in the area of the runoff basin (DBN V.2.5-75:2013, p. A.7, 2013];

$A$ and $n$ are parameters taking into account the geographical location of the city and period $P$, years, one-time probability of the calculated intensity of rainfall (DBN V.2.5-75:2013, p. A.2, 2013];

$F$ is the area of surface runoff basin entering the infiltration basin, ha.

For the infiltration basin, from which the retained water is drained through the collectors of the existing drainage network, the relative control volume $W_{r e g}^{\prime}$ is determined by the relation (Fig. 2).

$$
W_{\text {reg }}^{\prime}=a \cdot\left(q_{\text {act }}^{\prime}-1\right)^{2}-b \cdot\left(q_{\text {act }}^{\prime}-1\right),
$$

where: $a$ and $b$ are the empirical coefficients, which according to research (Tkachuk \& Yaruta, 2018; Yaruta, 2020) should be taken equal to the duration of the relative flow of runoff on the surface to the infiltration basin $t_{s}^{\prime}$ and in the pipelines of the drainage network $t_{p}$ (after the basin) before discharge into the reservoir: $a=t_{s}$ '; $b=t_{p}^{\prime} ;\left(t_{s}^{\prime}+t_{p}^{\prime}=t_{r}^{\prime}=1.0\right)$

$q_{a c t}^{\prime}$ is the relative flow rate of water actually discharged from the infiltration basin, and is equal to the ratio of drainage flow $q_{d r}$ to the estimated inflow $q_{r}: q_{a c t}^{\prime}=q_{d r} / q_{r}$.

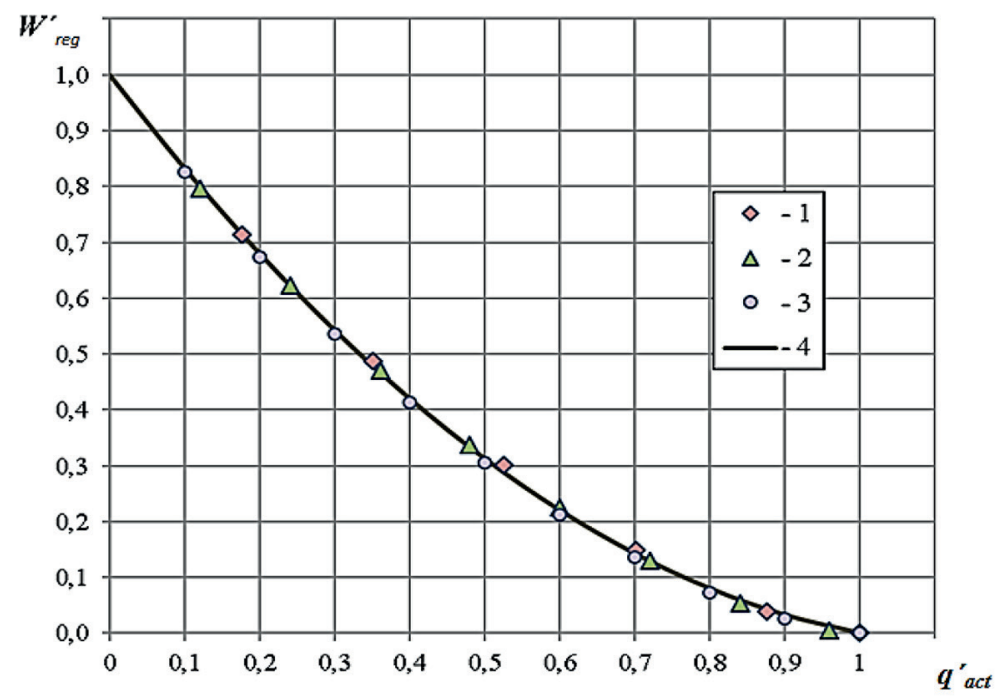

Figure 2. Dependence of the relative control volumes of infiltration basins $W_{r e g}^{\prime}$ on the relative capacity $q^{\prime}$ of the sewer: 1-3 are the numerical values corresponding to the hydrograph data at the points of the sewer at a distance from its beginning, respectively: $0.33 ; 0.67$ and $1.0 ; 4$ is line of analytical dependence (3) 


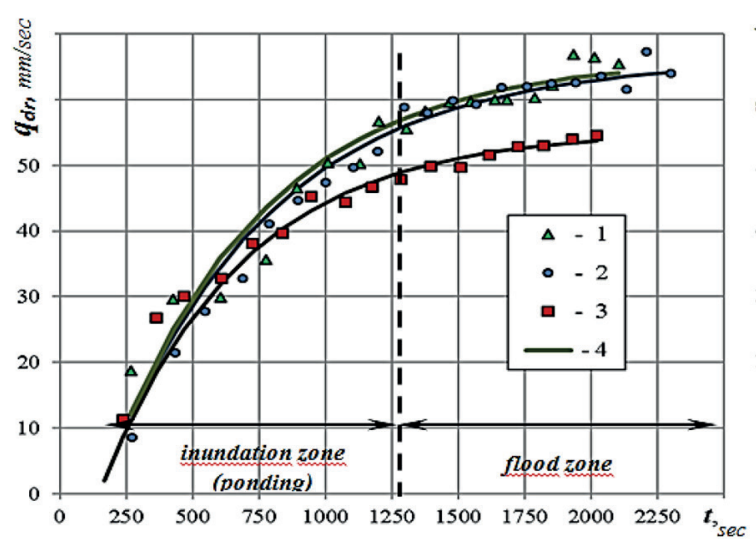

a)

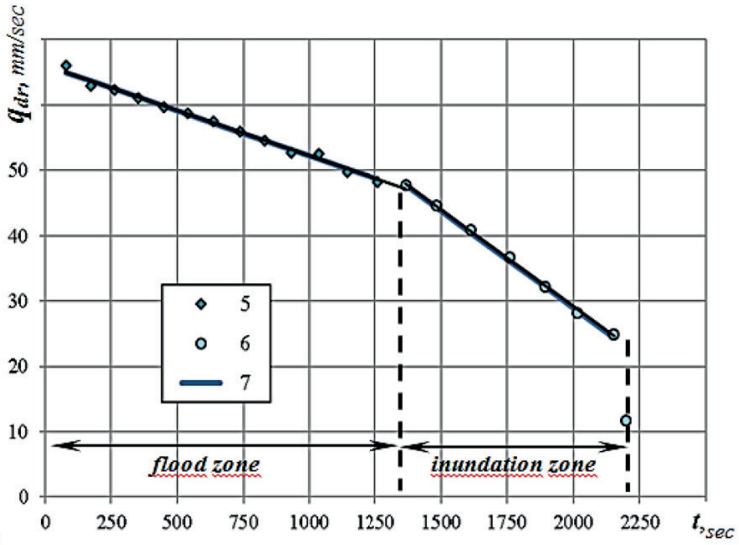

b)

Figure 3. Graphs of changes in drainage costs from the duration of infiltration when filling (a) and emptying (b) of the infiltration basin:n1 - the experimental data filling the basin with forced removal of air from the load; 2 - the same, wing air; 4 and 7 - the lines of analytical dependences; 3 - the experimental data of basin emptying in the zone of its inundation; 2 - the same, in the flood zone (emptying the load)

It was established that the drainage flow of water $\boldsymbol{q}_{d r}$, which is discharged from the infiltration basin, when filling it, both for the flood zone and for the flood zone changes by the exponential (Fig. 3a), and when emptying - by the linear relation (Fig. 3b) with breakpoint at the time of transition from the flood zone to the inundation zone. In this case, the maximum estimated drainage flow $\boldsymbol{q}_{\text {est.dr }}$ falls at the end of the storm. Provided that urban areas are not flooded, this cost should not exceed the actual capacity of the drainage network $\boldsymbol{q}_{a c t}$. This determines not only the control volumes of infiltration basins (formulas 1-3), but also the conditions of flow control at the outlet of them.

The depths of their laying are important for the drainage rainwater gravity flow when infiltration basins are connected to rainwater drainage collectors. The elevation marks of the drainage pipes located in the lower part of the building (Fig. 1) are tied up with the markings of the street collectors of the existing drainage network. The height of the accumulation layer of the basin depends on the depth of drainage, since the area of infiltration basin depends on its height.
Depending on the rate of water penetration into the basin, the rate of water penetration and filtration coefficients of the top plant layer, their areas and sizes were determined. In order to load infiltration basins with a typical vegetation upper layer, the ranges of changes in the values of water penetration rates and filtration coefficients were obtained (Tkachuk \& Yaruta (2019; Yaruta, 2020):

- water penetration velocities $=0.1-0.5 \mathrm{~mm} / \mathrm{sec}$;

- the filtration coefficients of the upper layer $=$ $0.16-0.36 \mathrm{~mm} / \mathrm{sec}$;

- filtration coefficients of the entire load $=1.1$ $2.2 \mathrm{~mm} / \mathrm{sec}$.

The absorbing properties of pavements with plant layers change during maintenance. Thus, during contaminated runoff filtration, the upper layers are clogged and their water-absorbing and filtration properties are reduced. In the dry weather period, due to the natural processes of plant life, these layers are self-regenerated with the restoration of their properties subject to the appropriate selection of plant species (perennial groups, monocotyledonous class with fibrous root system). The studies of pavements with a typical

Table 1. Changes in the filtration coefficients of the upper plant layers

\begin{tabular}{|c|c|c|c|c|c|c|}
\hline \multirow{2}{*}{$\begin{array}{c}\text { Sample } \\
\text { number }\end{array}$} & \multicolumn{7}{|c|}{ The value of the filtration coefficients Kf, mm/sec } \\
\cline { 2 - 7 } & Before clogging & After clogging & $\ln 1$ day & $\ln 2$ day & $\ln 6$ day & In 7 day \\
\hline 1 & 1.19 & 0.287 & 0.39 & 0.50 & 0.58 & 0.63 \\
\hline 2 & 0.13 & 0.105 & 0.22 & 0.27 & 0.32 & 0.38 \\
\hline 3 & 0.74 & 0.370 & 0.43 & 0.52 & 0.68 & 0.76 \\
\hline 4 & 0.87 & 0.342 & 0.40 & 0.47 & 0.53 & 0.59 \\
\hline 5 & - & 0.250 & 0.26 & 0.37 & 0.57 & 0.54 \\
\hline
\end{tabular}


plant layer for the discharge capacity of contaminated runoff of 25-40 minutes-rain duration defined that their filtration coefficients are reduced by 1.5-3 times, but after 6-7 days between the rainy season, their filtration and water absorption abilities are almost completely restored (Table 1).

It has been experimentally established that according to the main indicators of pollution (suspended solids, oil products, $\mathrm{BOD}_{5}$ ) the surface runoff is cleaned through the upper layers of the infiltration basin. According to the amount of suspended solids, BOD, oxidation, $\mathrm{pH}$ and dissolved oxygen, during the water filtration through the plant layers the quality of rain runoff decreases to the normative values (DSTU 8691:2016, 2016). However, chemical pollution of rainwater runoff (chemical fertilizers, industrial emissions, etc.) requires additional treatment, as in traditional drainage methods.

\section{CONCLUSIONS}

Regulation of surface runoff in urban areas with temporary delay of rainwater in the places of precipitation by infiltration basins and with the gradual discharge of these waters through the existing reservoirs of small diameters is the most appropriate in modern Ukrainian cities. The assessment of the conditions of infiltration basins application for the regulation of surface water drainage should be carried out by urban, technological, environmental and economic factors. On the basis of experimental studies as well as numerical computer modeling, the analytical dependences and sizes of the basic settlement parameters for the device of infiltration basins were received, whereas the clearing and self-regenerative restoring function of their vegetation was established. According to the amount of suspended solids, BOD, oxidation, $\mathrm{pH}$ and dissolved oxygen, the quality of rain runoff when filtering water through the upper vegetation layers of infiltration basins decreases to the normative values. Chemical contamination of rainwater runoff (chemical fertilizers, industrial emissions, etc.) requires additional treatment, as in traditional drainage methods.

\section{REFERENCES}

1. Boshota V.V. 2013. Rehulyuvannya doshchovoho stoku $\mathrm{z}$ urbanizovanykh terytoriy z vykorystannyam filtratsiynykh transhey. (Ph.D's) 05.23.04, Rivne, 20. [in Ukrainian]

2. DBN V.2.5-75:2013 2013. Sewerage. External networks and facilities. The main principles of the desig.
Kyiv, Minrehionbud Ukrainy, 211. [in Ukrainian]

3. DSTU 8691:2016. Stichni vody. Nastanovy shchodo vstanovlennya tekhnolohichnykh normatyviv vidvedennya doshchovykh stichnykh vod u vodni obyekty. Kyiv: DP, UkrNDNTS, 28. [in Ukrainian]

4. DSTU-N B V.1.1-38:20162016. Nastanova shchodo inzhenernoho zakhystu terytoriy, budivel i sporud vid pidtoplennya ta zatoplennya. Kyiv: Minrehion Ukrainy, 204. [in Ukrainian]

5. Dziopak J. 2015. Stormwater Management and Retention in Urban Catchment. Storm Water Management: Examples from Czech Republic, Slovakia and Poland. Springer Switzerland, 43-66.

6. Fletcher T.D., Andrieu H., Hamel P. 2013. Understanding, management and modeling of urban hydrology and its consequences for receiving waters: a state of the art/Advances in Water Resources, Pergamon, 51, 261-279.

7. Kaźmierczak A. 2013. Innowacyjne metody wspierania tworzenia zielonej infrastruktury w miastach: współpraca władzlokalnych zinwestorami i właścicielami budynków. Zrównoważony Rozwój Zastosowania, 4, 98-109. [in Polish].

8. Low impact development stormwater management planning and design guide 2020. URL: https://cvc. ca/wp-content/uploads/2014/04/LID-SWM-Guidev1.0_2010_1_no-appendices.pdf.

9. Lucke T., Nichols P.W.B. 2015. The pollution removal and stormwater reduction performance of streetside bioretention basins after ten years in operation. Science of The Total Environment, 536, 784-792. https://doi.org/10.1016/J.scitotenv.2015.07.142

10. Shevchuk O.V. 2017. Obgruntuvannya rozrakhunkovykh parametriv infiltratsiynykh maydanchykiv u miskykh systemakh doshchovoho vodovidvedennya. Ph.D's thesis: 05.23.04. Rivne, 200. [in Ukrainian]

11. Tkachuk O.A., Yaruta Y.V. 2018. Osoblyvosti formuvannya doshchovoho stoku na miskykh terytoriyakh. Tekhnichni nauky: zb. nauk. prats. Rivne: NUWEE, 1(81), 63-74. [in Ukrainian]

12. Tkachuk O.A., Yaruta Y.V. 2019. Ochyshchennya doshchovoho stoku pry yoho rehulyuvanni za dopomohoyu infiltratsiynykh baseyniv. Naukovyy Visnyk Budivnytstva, 95(1), 204-211. [in Ukrainian]

13. Ukrainian Hydrometeorological Center: Climate system and factors determining the formation of climate 2021. URL: https://meteo.gov.ua/ua/33345/ climate/climate/.

14. Yaruta Y.V. 2020. Udoskonalennya miskykh system doshchovoho vodovidvedennya $\mathrm{z}$ urakhuvannyam rehulyuvannya doshchovoho stoku. (Ph.D's) 192, Construction and Civil Engineering, 247. [in Ukrainian]

15. Zhuk V.M., Kachmar I.Z. 2015. Teoretychnyy rozrakhunok nakopychennya doshchovoho stoku na poverkhni udoskonalenykh pokryttiv. Visnyk NU "Lvivska Politekhnika". Teoriya i Praktyka Budivnytstva, 520, 122-128. [in Ukrainian] 